\author{
URL: http://ejournalfia.ub.ac.id/index.php/jiap
}

\title{
Inovasi Pelayanan Publik (Studi pada Pelayanan Kesehatan Melalui Program Gebrakan Suami Siaga di Puskesmas Gucialit Kabupaten Lumajang)
}

\author{
Arik Ariyani ${ }^{a} *$, Lely Indah Mindarti ${ }^{\text {a }}$ dan Mohammad Nuh ${ }^{\text {a }}$ \\ ${ }^{a}$ Universitas Brawijaya, Malang, Jawa Timur, Indonesia
}

\section{INFORMASI ARTIKEL}

\section{Article history:}

Dikirim tanggal: 20 September 2016

Revisi pertama tanggal: 05 Oktober 2016

Diterima tanggal: 09 November 2016

Tersedia online tanggal: 28 November 2016

Keywords: innovation, services, public sector, health

\begin{abstract}
Maternal Mortality Rate (MMR) and Infant Mortality Rate (IMR) in Indonesia is still high. The central government and the local governments charged jointly conduct various innovative efforts of health. As an example of Puskesmas Gucialit Lumajang in addressing the issue of high maternal and infant mortality in the region through Program breakthrough husband standby. The results showed that the standby husband breakthrough innovation has been implemented properly. Many services provided, quality of service is better, and showed the declining trend in maternal and infant mortality in the region Gucialit. Program breakthrough husband standby innovation success capable of being expanded into a container that is wider in 2013 through a program dear mother and child.
\end{abstract}

\section{INTISARI}

Angka Kematian Ibu (AKI) dan Angka Kematian Bayi (AKB) di Indonesia tergolong masih tinggi, untuk itu pemerintah pusat maupun pemerintah daerah dituntut bersama-sama melakukan berbagai usaha-usaha inovatif pelayanan kesehatan. Sebagai contoh yaitu Puskesmas Gucialit Kabupaten Lumajang dalam mengatasi permasalahan tingginya Angka Kematian Ibu dan Bayi di wilayahnya melalui sebuah inovasi gebrakan suami siaga. Hasil penelitian menunjukan bahwa inovasi gebrakan suami siaga sudah dilaksanakan dengan baik. Banyak pelayanan yang diberikan, kualitas pelayanan lebih baik, dan menujukkan keberhasilan penurunan angka kematian ibu dan bayi di wilayah Gucialit, selain itu keberhasilan inovasi gebrakan suami siaga mampu dikembangkan kedalam wadah yang lebih luas ditahun 2013 melalui program sayang ibu dan anak.

2016 FIA UB. All rights reserved.

\section{Pendahuluan}

Angka Kematian Ibu (AKI) dan Angka Kematian Bayi (AKB) merupakan salah satu indikator yang penting dalam mengukur tingkat derajat kesehatan masyarakat suatu negara. Angka Kematian Ibu (AKI) dan Angka Kematian Bayi (AKB) di Indonesia tergolong masih tinggi. Berdasarkan Survei Demografi dan Kesehatan Indonesia (SDKI) Tahun 2012, Angka
Kematian Ibu (AKI) (yang berkaitan dengan kehamilan, persalinan, dan nifas) mencapai 359 per 100.000 kelahiran hidup, sedangkan angka kematian bayi (AKB) mncapai 32 per 1000 kelahiran hidup (Depkes RI, 2015).

Masih ada daerah pedesaan di Indonesia yang menyumbangkan Angka Kematian Ibu (AKI) dan Angka Kematian Bayi (AKB). Dengan dikeluarnya

* Corresponding author. Tel.: +62-812-5205-3369; e-mail: lelyindahmindarti@gmail.com 
Peraturan Pemerintah Republik Indonesia, Nomor 6 Tahun 2008 tentang Pedoman Evaluasi Penyelenggaraan pemerintah Daerah (EPPD); pemerintah daerah dituntut untuk turut berkontribusi dalam upaya permasalahan tersebut melalui program-program inovatif. Gucialit yaitu sebagai contoh kecamatan di Kabupaten Lumajang yang memiliki Angka Kematian bayi tinggi dan masih terjadi kematian ibu diwilayah tersebut di Tahun 2010 yaitu terdapat 23 kematian bayi dan 1 kematian ibu, hal tersebut disebabkan oleh berbagai macam faktor yaitu faktor ekonomi, faktor geografi dan faktor budaya patrilinial masyarakat setempat.

Melihat banyaknya akar permasalahan yang ada di Kecamatan Gucialit Kabupaten Lumajang tersebut dan dengan mengacu pada keluarnya Peraturan Pemerintah Republik Indonesia, Nomor 6 Tahun 2008 tentang Pedoman Evaluasi Penyelenggaraan Pemerintah Daerah (EPPD); Puskesmas Gucialit turut berkontribusi dalam meminimalisir permasalahan tingginya angka kematian ibu dan bayi yaitu melalui inovasi gebrakan suami siaga. Program ini bertujuan untuk meningkatkan pengetahuan, keterlibatan dan partisipasi suami terhadap pelayanan kesehatan ibu dan bayi baru lahir, dengan harapan mampu menekankan Angka Kematian Ibu dan Angka Kematian Bayi di wilayah Gucialit.

Berdasarkan uraian diatas maka penulis merumuskan masalah, antara lain bagaimanakah inovasi pelayanan kesehatan gebrakan suami siaga di Puskesmas Gucialit Kabupaten Lumajang; Apa saja hasil dari inovasi pelayanan kesehatan gebrakan suami siaga di Puskesmas Gucialit Kabupaten Lumajang; Apa saja faktor-faktor pendukung dan penghambat inovasi pelayanan kesehatan gebrakan suami siaga di Puskesmas Gucialit Kabupaten Lumajang. Adapun tujuan penelitian adalah untuk mendiskripsikan bagaimana inovasi gebrakan suami siaga, hasil dari inovasi gebrakan suami siaga, dan faktor pendukung dan penghambat dari inovasi gebrakan suami siaga di Puskesmas Gucialit Kabupaten Lumajang.

\section{Teori}

\subsection{Administrasi Publik}

\subsubsection{Definisi Administrasi Publik}

Administrasi publik diungkapkan Caiden dalam Mindarti (2007:3) merupakan seluruh kegiatan administrasi publik untuk segenap urusan publik (public administration). Jadi seluruh kegiatan yang bersangkutan dengan urusan publik dapat disebut dengan administrasi publik.

\subsubsection{Kaitan Administrasi Publik dengan Pelayanan Publik}

Teori ilmu administrasi publik menurut Siagian yang dikutip oleh Hardiansyah (2011:10) administrasi publik mengajarkan bahwa pemerintahan negara pada hakikatnya menyelenggarakan dua fungsi utama, yaitu fungsi pengaturan dan fungsi pelayanan. Fungsi pengaturan biasanya dikaitkan dengan hakikat negara modern sebagai suatu negara hukum (legal state), sedangkan fungsi pelayanan dikaitan dengan hakikat negara sebagai suatu negara kesejahteraan (welfare state).

\subsection{Inovasi}

\subsubsection{Pengertian Inovasi}

Menurut Muluk (2008:42) inovasi di sektor publik dilaksanakan dalam rangka meningkatkan efisiensi dan mengurangi biaya mengingat pada dasarnya organisasi sektor publik senantiasa menghadapi kelangkaan sumber daya dan keterbatasan anggaran. Inovasi juga dapat dimanfaatkan untuk meningkatkan kualitas pelayanan dan dampaknya bagi masyarakat terutama untuk mengatasi kebijakan yang sebelumnya yang kurang menampakkan hasil yang memuaskan.

\subsubsection{Atribut Inovasi}

Terdapat lima macam atribut inovasi menurut Rogers yang dikutip oleh Suwarno (2008:17), meliputi:

a) Relative Advantage atau keuntungan relative;

b) Compatibilty atau kesesuaian;

c) Complexity atau kerumitan;

d) Triability atau kepemimpinan dicoba; dan

e) Observability atau kemudahan diamati.

\subsubsection{Tipologi Inovasi}

Menurut Mulgan \& Alburry yang dikutip oleh Muluk (2008:44) menyatakan ada lima tipologi dalam proses inovasi, yaitu:

a) Inovasi produk atau layanan;

b) Inovasi proses pelayanan;

c) Inovasi metode pelayanan;

d) Inovasi kebijakan; dan

e) Inovasi sistem.

\subsubsection{Difusi Inovasi}

Difusi inovasi terdiri dari 2 kata, yaitu difusi dan inovasi. Rogers 1995 (dalam Sciffman dan Kanuk, 2010) mendefinisikan difusi sebagai proses dimana suatu inovasi dikomunikasikan melalui saluran tertentu dalam jangka waktu tertentu diantara para anggota suatu sistem sosial. Menurut Suwarno (2008:13) dikenal dua jenis model difusi, yaitu model difusi pengaruh internal dan model difusi pengaruh eksternal.

\subsubsection{Proses dan Siklus Pengembangan Inovasi}

Proses pengembangan inovasi menurut Suwarno (2008:19) melewati tahapan sebagai berikut:

a) Kebutuhan atau masalah;

b) Riset Dasar dan Aplikatif;

c) Pengembangan;

d) Komersialisasi; 
e) Difusi dan Adopsi; dan

f) Konsekuensi.

\subsubsection{Pengembangan Sistem inovasi Publik}

Menurut Muluk (2008:49) ada beberapa faktor kritis dalam pengembangan inovasi, antara lain sebagai berikut:
a) Pengembangan Kepemimpinan Inovasi;
b) Pengembangan Budaya Inovasi;
c) Pengembangan Pegawai;
d) Pengembangan Tim kerja dan Kemitraan;
e) Pengembangan kinerja Inovasi; dan
f) Pengembangan jaringan inovasi.

\subsubsection{Faktor Pendukung dan Penghambat Inovasi}

a) Faktor Pendukung

Menurut Ancok (2012:58) ada tiga mendukung inovasi, yakni sebagai berikut:

- Modal manusia;

- Modal kepemimpinan; dan

- Modal srtuktur ogranisasi.

b) Faktor Penghambat

Mulgan and Albury dalam Noor (2013:27) ada delapan hambatan inovasi pada sektor publik, yaitu sebagai berikut:

- Keengganan untuk menutup program yang gagal;

- Ketergantungan yang berlebihan pada tampilan kinerja tinggi sebagai sumber inovasi;

- Teknologi yang tersedia, tetapi menghambat budaya atau organisasi;

- Tidak ada imbalan atau intensif untuk berinovasi atau mengadopsi inovasi;

- Tidak berani mengambil resiko;

- Anggaran jangka pendek dan perencanaan;

- Tekanan dan hambatan administratif; dan

- Budaya risk aversion.

\subsection{Pelayanan Publik}

\subsubsection{Pengertian Pelayanan Publik}

Menurut Keban yang dikutip oleh Jumara (2010:16) menyebutkan dalam konteks pelayanan publik lebih dititik beratkan kepada bagaimana elemen-elemen administrasi publik seperti policy making, desain organisasi, dan proses manajemen dimanfaatkan untuk menyukseskan pemberian pelayanan publik, dimana pemerintah merupakan pihak provider yang diberi tanggung jawab.

\subsubsection{Prinsip-Prinsip Pelayanan Publik Sinambela} (2008:48)
a) Akuntabilitas (accountablity);
b) Transparasi (transparency);
c) Keterbukaaan (openess);
d) Berdasarkan Hukum (rule of low); dan
e) Jaminan (fairness);

\subsubsection{Kualitas Pelayanan menurut Sinambela (2008:6)}

a) Transparansi;

b) Akuntabilitras;

c) Kondisional;

d) Partisipatif;

e) Kesamaan hak; dan

f) Keseimbangan hak dan kewajiban.

\subsection{Pelayanan Kesehatan}

\subsubsection{Pengertian Pelayanan Kesehatan}

Menurut Lovely dan Loomba dalam Eryando (2007:30) yang dimaksud dengan pelayanan kesehatan adalah setiap upaya yang diselenggarakan atau secara bersama-sama dalam suatu organisasi untuk memelihara dan meningkatkan kesehatan perseorangan, kelompok, keluarga, dan ataupun masyarakat.

a) Mutu Pelayanan Kesehatan

Longest dalam buku Management Practices for the Health Profesional (1976) yang dikutip oleh Marjati (2013:3) ada banyak aspek yang dapat dipakai untuk menilai mutu pelayanan kesehatan dapat dinilai dari struktur pelayanan itu sendiri dan bagaimana bentuk pelayanan yang diberikan yang meliputi ruang lingkup pelayanan, tingkat pendidikan yang memberikan pelayanan atau berbagai karakteristik lainnya.

b) Standar Pelayanan Kesehatan

Pohan (2004:28) menjelaskan pengertian dari standar layanan kesehatan yaitu merupakan suatu alat organisasi untuk menjabarkan mutu layanan kesehatan kedalam terminologi operasional sehingga semua orang yang terlibat dalam layanan kesehatan akan terikat dalam suatu sistem, baik pasien, penyedia layanan kesehatan, penunjang layanan kesehatan, ataupun manajemen organisasi layanan kesehatan dan akan bertanggung gugat dalam melaksanakan tugas dan perannya masing-masing.

\subsection{Puskesmas}

\subsubsection{Pengertian Puskesmas}

Puskesmas menurut Satrianegara (2014:72) adalah suatu kesatuan organisasi kesehatan fungsional yang merupakan pusat pengembangan kesehatan masyarakat yang juga membantu peran serta menyeluruh dan terpadu kepada masyarakat diwilayah kerjanya dalam bentuk kegiatan pokok.

\subsubsection{Wilayah Kerja dan Ruang Lingkup Pelayanan Puskesmas}

Pembagian wilayah kerja puskesmas ditetapkan oleh bupati atau walikota, dengan saran teknis dari kepala dinas kesehatan kabupaten/ kota. Sasaran penduduk yang dilayani oleh puskesmas rata-rata mencapai 30.000 penduduk setiap puskesmas (Satrianegara, 2014:72). 


\subsubsection{Fungsi dan Peran Puskesmas}

Berikut adalah fungsi dan peran puskesmas menurut Satrianegara (2014:74), adalah sebagai berikut:

a) Sebagai pusat penggerak penggerak pembangunan berwawasan kesehatan masyarakat diwilayah kerjanya;

b) Pusat pemberdayaan masyarakat; dan

c) Pusat kesehatan pertama.

\subsubsection{Penilaian Mutu Pelayanan Puskesmas}

Upaya peningkatan mutu pelayanan puskesmas seperti yang diungkapkan oleh Satrianegara (2014:136) merupakan suatu proses manajemen yang dilakukan secara sistematis, objektif, terpadu dan berkesinambungan serta berorientasi pada pelanggan. Peningkatan mutu pelayanan kesehatan puskesmas akan tercapai, jika proses pelayanan diperbaiki dengan menerapkan prinsip dan jaminan mutu.

\section{Metode Penelitian}

Jenis penelitian yang digunakan adalah penelitian deskriptif dengan pendekatan kualitatif. Faisal (2003:20) menyebutkan bahwa penelitian deskriptif adalah suatu penelitian yang dimaksudkan untuk eksplorasi dan klarifikasi mengenai sesuatu fenomena atau kenyataan sosial, dengan jalan mendeskripsikan sejumlah variabel yang berkenaan dengan masalah dan unit yang diteliti. fokus dalam penelitian ini, adalah sebagai berikut:

a) Bagaimana inovasi pelayanan kesehatan melalui Program Gebrakan Suami Siaga yang diterapkan oleh Puskesmas Kecamatan Gucialit yang meliputi bentuk inovasi, proses dan siklus inovasi; serta difusi inovasi pada Puskesmas Gucialit;

b) Bagaimanakah hasil dari inovasi pelayanan kesehatan Program Gebrakan Suami Siaga di Puskesmas Gucialit Kabupaten Lumajang yang meliputi kualitas layanan; hasil terhadap angka kematian ibu dan bayi; serta tindak lanjut program suami siaga; dan

c) Faktor yang mendukung dan menghambat inovasi pelayanan kesehatan melalui Program Gebrakan Suami Siaga yang meliputi faktor pendukung (faktor internal dan faktor eksternal) serta faktor penghambat (faktor internal dan faktor eksternal).

Lokasi penelitian yang dipilih oleh penulis adalah Kecamatan Gucialit Kabupaten Lumajang. Kemudian situs penelitian antara lain: Puskesmas Gucialit Kabupaten Lumajang dan masyarakat Kecamatan Gucialit khususnya ibu hamil. Sumber data dibagi menjadi tiga yaitu: (1) informan meliputi: Kepala Puskesmas, Kasubag Tata Usaha, Bidan Puskesmas Gucialit, Masyarakat Gucialit Kabupaten Lumajang, (2) dokumen, (3) peristiwa. Jenis data terdiri dari data primer bersumber dari: Kepala Puskesmas Kecamatan Gucialit, pegawai Puskesmas, bidan di Puskesmas, serta masyarakat Gucialit khususnya ibu hamil, dan data skunder diperoleh dari dokumen-dokumen, foto, komplikasi data, laporan, catatan-catatan di Puskesmas Gucialit Kabupaten Lumajang.

Pengumpulan data dilakukan melalui observasi, wawancara dan dokumentasi. Instrumen penelitian yaitu peneliti sendiri, pedoman wawancara, catatan lapangan, dan perangkat penunjang. Analisis data yang digunakan adalah analisis data model Miles, Huberman dan Saldana, (2014:8) menjelaskan ada 4 tahap yaitu: pengumpulan data, kondensasi data, penyajian data, dan kesimpulan.

\section{Hasil Penelitian dan Pembahasan}

\subsection{Inovasi Layanan}

\subsubsection{Bentuk Inovasi}

Pelayanan, inovasi metode pelayanan, inovasi kebijakan, dan inovasi sistem. Inovasi Suami Siaga yang dicanangkan Puskesmas Gucialit ini termasuk kedalam tipologi inovasi yaitu inovasi metode layanan. Program ini termasuk suatu hal baru/ cara baru sebuah puskesmas dalam memberikan pelayanan yang lebih baik pada masyarakat yaitu berupa pendampingan langsung pada masyarakat, melalui sebuah pelatihan khusus terhadap masyarakat setempat mengenai pengetahuan tentang masalah kehamilan. Pendampingan langsung kepada masyarakat setempat khususnya ibu hamil dan suami yang meliputi 3 (tiga) tahap proses gebrakan suami siaga yaitu pembekalan, pelaksanaan, dan evaluasi hasil pelatihan.

\subsubsection{Proses dan Siklus Inovasi}

Inovasi gebrakan suami siaga di Puskesmas Gucialit mengalami tahapan proses dan siklus pada penerapannya, antara lain sebagai berikut:

a) Proses mengenali masalah melalui minlok bulanan dan FGD;

b) Riset dasar dengan cara pelatihan pegawai dan peningkatan alat kesehatan;

c) Mengadakan FGD kesepakatan antar tim adanya pelatihan suami siaga;

d) Disosialisasikan;

e) Diimpelentasikan; dan

f) Dikembangkan.

\subsubsection{Difusi Inovasi}

Ada beberapa karakteristik yang menjadi penentu adopter dalam menerima inovasi yaitu difusi inovasi terdiri dari difusi internal meliputi status sosio-ekonomi yang dimiliki masyarakat yang rendah karena tingkat ekonomi yang rendah menyebabkan rendahnya pengetahuan yang dimiliki dan tentunya mempengaruhi kecepatan individu dalam menerima inovasi. Rendahnya status ekonomi sosial masyarakat juga berbanding lurus dengan variabel pribadi yang dimiliki masyarakat, 
perilaku komunikasi juga mempengaruhi individu dalam menerima inovasi. Tingkat komunikasi masyarakat kecamatan Gucialit cukup tinggi sehingga inovasi tidak mengalami masalah pada perilaku komunikasi masyarakat dan difusi eksternal yaitu keadaan georafis wilayah Gucialit mempengaruhi kecepatan adopter dalam menerima inovasi, karena diwilayah Gucialit dulu memiliki medan yang sulit yaitu jalan belum beraspal dan menanjak.

\subsection{Hasil dari inovasi}

\subsubsection{Kualitas Pelayanan di Puskesmas Gucialit}

Pelayanan publik secara teoritis pada dasarnya mempunyai tujuan utama yaitu memuaskan masyarakat dengan memberikan kualitas pelayanan terbaik pada masyarakat. Puskesmas Gucialit sudah menjalankan fungsinya dengan baik dalam memberikan pelayanan yaitu: (1) masyarakat Gucialit mengetahui dan memahami inovasi gebrakan suami siaga yang ada di Puskesmas; (2) dapat dipertanggungjawabkan dibuktikan dengan adanya data cakupan variabel penilaian kinerja puskesmas program pokok/ wajib; (3) masyarakat mendapatkan penanganan yang lebih baik di Puskesmas Gucialit sejak adanya inovasi; (4) Dengan adanya inovasi Puskesmas Gucialit mampu memperhatikan aspirasi, kebutuhan dan harapan dari masyarakat setempat khususnya pemberian pelayanan kepada ibu hamil; (5) petugas di Puskesmas Gucialit sangat ramah kepada setiap warga yang datang dan tidak ada perbedaan pelayanan yang diberikan antara masyarakat miskin dan kaya; dan (6) sudah memperhatikan hak dan kewajiban antara petugas dan masyarakat.

\subsubsection{Hasil terhadap Angka Kematian Ibu dan Bayi}

Menurut hasil penelitian sejak diberlakukannya Inovasi Gebrakan Suami siaga kematian bayi yang turun secara signifikan di Tahun 2011 hingga sekarang dibandingkan Tahun 2008 dan 2009. Yaitu untuk kematian ibu di Tahun 2010 turun menjadi 0 ditahun 2011 dan hingga sampai sekarang. Untuk kematian bayi dari 23 kematian menjadi 17 di Tahun 2011, kemudian turun lagi di Tahun 2012 menjadi 12, kemudian 8 kematian di Tahun 2013, turun lagi di Tahun 2014 menjadi 4, dan data terakhir di Tahun 2015 menjadi 3 kematian bayi.

\subsubsection{Tindak Lanjut Pelaksanaan Program Gebrakan Suami Siaga}

Pengembangan sistem inovasi pada suatu organisasi sektor publik sangatlah penting yaitu digunakan sebagai arahan bagi inovasi secara berkelanjutan. Berdasarkan hasil penelitian pada penyajian data keberlanjutan dari inovasi gebrakan suami siaga tidak luput dari pengembangan kepemimpinan pada pergantian kepemimpinan, pengembangan budaya inovasi dengan berpegang teguh pada visi puskesmas yakni meningkatkan pelayanan kesehatan dasar, pengembangan pegawai dengan melakukan pelatihan pada seluruh tim dari puskesmas, pengembangan tim dan kemitraan dengan melakukan sosialisasi internal, pengembangan kinerja inovasi, dan pengembangan jaringan inovasi yaitu koordinasi antar lembaga yang melibatkan lintas sektor dan lintas program.

\subsubsection{Faktor Pendukung dan Penghambat Inovasi Gebrakan Suami Siaga di Puskesmas Gucialit}

\section{a) Faktor Pendukung}

Faktor inovasi gebrakan suami siaga berasal dari dalam meliputi modal manusia yang dimiliki pegawai yakni kreatifitas, sosial, dan keuletan, modal kepemimpinan dan modal struktur organisasi.dan luar puskesmas. Sedangkan faktor pendukung eksternal adalah koordinasi antar lembaga yang melibatkan lintas sektor dan lintas program, dan partisipasi dari masyarakat setempat.

\section{b) Faktor Penghambat}

Faktor penghambat dari inovasi gebrakan suami siaga berasal dari dalam meliputi ketersediaan dana, sarana prasarana dan kuantitas (jumlah) tim dari program suami siaga dan luar puskesmas, yaitu tingkat sumber daya manusia masyarakat yang rendah dan masih adanya budaya patrilinial dari masyarakat setempat.

\section{Kesimpulan}

Berdasarkan hasil pembahasan didapatkan kesimpulan bahwa inovasi gebrakan suami siaga di Puskesmas Gucialit Kabupaten Lumajang merupakan sebuah inovasi metode pelayanan yang terdiri dari tiga pelayanan yaitu pembekalan, pelaksanaan, dan evaluasi hasil pelatihan. Inovasi gebrakan suami siaga memiliki kualitas pelayanan yang baik transparansi, akuntabilitas, kondisional dan partisipatif, kesamaan hak, keseimbangan hak dan kewajiban. Inovasi Gebrakan Suami siaga terbukti memberikan hasil pada penurunan Angka Kematian Ibu dan bayi. Yaitu untuk kematian ibu di Tahun 20101 menjadi 0 ditahun berikutnya sampai dengan Tahun 2015, dan terdapat 23 kematian bayi di Tahun 2010 turun sampai dengan 3 kematian bayi di Tahun 2015. Inovasi gebrakan suami siaga juga mampu dikembangkan kedalam wadah yang lebih luas melalui gerakan sayang ibu dan anak di Tahun 2013, namun dalam pelaksanaannya adapun yang menjadi faktor pendorong dan pengmambat faktor pendorong antara lain yaitu modal manusia yang dimiliki pegawai, modal kepemimpinan, modal struktur organisasi, koordinasi antar lembaga dan partisipasi masyarakat setempat, sedangkan faktor penghambat yaitu ketersediaan dana, sarana prasarana dan kuantitas (jumlah) tim, tingkat 
sumber daya manusia masyarakat yang rendah dan masih adanya budaya patrilinial dari masyarakat setempat.

\section{Daftar Pustaka}

Ancok, Djamaludin. (2012). Psikologi Kpemimpinan dan Inovasi. Jakarta :Erlangga.

Depkes RI. (2001). Profil Kesehatan Indonesia 2001: (Menuju Indonesia Sehat). Jakarta: Kementerian Kesehatan RI.

Depkes RI. (2015). Profil Kesehatan Indonesia Tahun 2014: (Health Statistics). Jakarta: Kementerian Kesehatan RI.

Eryando, Tris. (2007). Aksesbilitas Kesehatan Maternal di Kabupaten Tangerang. Jakarta: Universitas Indonesia.

Faisal, Sanapiah. (2003). Format-format Penelitian Sosial. Jakarta: PT Raja Grafindo Persada.

Hardiansyah. (2011). Kualitas Pelayanan Publik: Konsep, Dimensi, Indikator dan Implementasinya. Yogyakarta: Gava Media.

Jumara, Noorsyamsa. (2010). Manajemen Pelayanan Inklusif (Sebuah Gambaran Singkat dan Langkah Pengukuran). Jakarta: Lembaga Administrasi Negara.

Marjati, Pipitcahyani., Tatarini, Ika., \& Sondakh, Jenny J.S. (2013). Mutu Pelayanan Kesehatan dan Kebidanan. Jakarta: Salemba Medika.

Miles, Mathew B.A., Michael Huberman., \& Saldana. (2014). Analisis Data Kualitatif, Penerjemah Tjetjep Rohendi Rohidi. UI Press, Jakarta.

Mindarti, Lely Indah. (2007). Revolusi Administrasi Publik. Malang: Banyumedia.

Moleong, Lexy J. (2011). Metodologi Penelitian Kualitatif. Bandung: Remaja Rosdakarya.

Muluk, M.R. Khairul. (2008). Knowledge Management (Kunci Sukses Inovasi Pemerintah Daerah). Malang: Banyumedia.

Noor, Irwan. (2013). Desain Inovasi Pemerintahan Daerah. Malang: Ub press.

Peraturan Presiden Republik Indonesia No 6 Tahun 2008 tentang EPPD.

Pohan, Imbalo S. (2004). Jaminan Mutu Pelayanan Kesehatan (Dasar-dasar Pengertian dan Penerapan). Jakarta: EGC.

Satrianegara, M. Fais. (2014). Organisasi dan Manajemen Pelayanan Kesehatan (Teori dan Aplikasi dalam Pelayanan Puskesmas dan Rumah Sakit). Jakarta: Salemba Medika.

Schiffman., dan Kanuk. (2010). Perilaku Konsumen. Jakarta: PT. INDEK.

Sinambela, Lijan Poltak. (2008). Reformasi Pelayanan Publik: (Teori Kebijakan dan Implementasi). Jakarta: Bumi Aksara.
Suwarno, Yogi. (2008). Inovasi di Sektor Publik. Jakarta: STIA-LAN Press. 